\title{
DE AUTORITEIT VAN DE BELIJDENIS
}

Het probleem, dat wij met het spreken over de autoriteit van de belijdenis aansnijden, staat terstond levensgroot voor ons, zo we met enkele belijdenisuitspraken inzetten.

\section{Belijdenisacte als existentiële beslissing of dogmatiek}

Als een Jood in de apostolische tijd met mond en hart beleed: „Jezus is de Christus" of een heiden openlijk getuigde: „Jezus is de Kurios", dan was dit als geloofsacte een existentiële beslissing, die zijn ganse bestaan tot in de wortelvezelen toe raakte. En zonder restrictie mogen we op deze belijdenisacte het woord van Christus toepassen: „Vlees en bloed heeft u dit niet geopenbaard, maar mijn Vader, die in de hemelen is", en tevens het woord van Paulus: „Niemand kan zeggen Jezus de Kurios te zijn dan door de Heilige Geest". Wat de belijdenisinhoud aangaat, zeggen we zonder aarzeling: volstrekt normatief, omdat het als een zuivere weerklank op de krachtdadige duidelijkheid van Gods openbaring in de Heilige Schrift aangaande zijn Zoon geboren is.

Belijd ik daarentegen met het achtste artikel van de Nederlandsche Geloofsbelijdenis, dat er in het eene wezen Gods drie Personen zijn en dan met dit artikel de distinctie persoon nader omschrijf als een zelfstandigheid (in de franse editie: een subsistentie, in de latijnse, een hypostase genoemd) in het wezen Gods, die door een onmededeelbare eigenschap van de anderen onderscheiden is, dan gevoelt ieder, dat we hier in een geheel ander klimaat terecht gekomen zijn. Al zou men ook geneigd zijn met dr. Koopmans in zijn dissertatie te zeggen, dat de rekening van de geschiedenis der Triniteitsleer niet helderder en korter kan worden opgemaakt, dan zal toch tegelijkertijd erkend moeten worden, dat hier met behulp van bepaalde categoriale bepalingen der filosofie, die zeer duidelijk tijdgebonden zijn, dingen gezegd worden, die geen sterveling begrijpt. Hier zal men tussen affirmatie en presentatie scherp moeten onderscheiden. En de vraag dringt zich aan ons op: Is dit een ware christelijke belijdenis? Is dit de taal der aanbidding, die vandaag het hart raakt? Ik zou niet graag de dominees de kost willen geven, die niet weten wat een subsistentie of een hypostase is. Dit is een stukje dogmatiek en geen belijdenis van de gemeente Gods, waarvan we kunnen zeggen: Dit geloven wij met het hart en belijden wij met de mond.

\section{Homologie}

Met deze voorbeelden zitten we wat de autoriteit van de belijdenis betreft terstond medias in res. Om hier verder te komen, moeten we eerst vanuit het Nieuwe Testament de constitutieve elementen van homologein en homologie vastleggen en daarbij nauwkeurig nagaan waarop dit betrokken wordt. Drie karakteristieke momenten 
springen en elk geval duidelijk naar voren: de openbaarheid, het genormeerd zijn en het forensisch karakter.

Allereerst de openbaarheid. Met het hart gelooft men, met de mond belijdt men, zo horen we Paulus spreken, tot zaligheid (Rom. $10: 10)$. In Hebr. $13: 15$ wordt het belijden als de vrucht der lippen die Godsnaam belijden en zo als het Nieuw testamentisch lofoffer omschreven. Met een variant op een Russisch spreekwoord zou men kunnen zeggen: Belijden kan evenmin verborgen blijven als hoesten.

Daarbij komt het genormeerd zijn. Nergens wordt belijden in het Nieuwe Testament als een spontane, onverbindende zaak, een vrijblijvende aangelegenheid getekend. Als geloofsacte is het homologein, dat letterlijk ,hetzelfde zeggen" betekend, de toestemming met mond en hart van het evangelie Gods en het zich daardoor laten bepalen. Als geloofsinhoud - de overgang van het belijden als daad naar het belijden als inhoud vindt reeds binnen het Nieuwe Testament plaats - ziet het steeds op het evangelie Gods in Jezus Christus. Paulus spreekt van het gehoorzaam belijden van het evangelie van Christus (2 Cor. $9: 13$ ). De onbekende auteur van de brief aan de Hebreën roept de gemeente op tot het vasthouden aan de homologie van Jezus Christus de Zoon van God. De apostel Johannes verklaart „Iedere geest, die belijdt dat Jezus Christus in het vlees gekomen is, is uit God. En iedere geest, die Jezus niet belijdt, is uit God niet" ( 1 Joh. $4: 2,3$ ).

In de derde plaats hebben we het forensisch karakter van het belijden genoemd. Michel noemt in het Theologische Wörterbuch dit zelfs het belangrijkste moment in het belijden. Onder dit forensisch karakter wordt verstaan het getuigenis afleggen, het verantwoording doen voor een bepaald forum, dat zich daarvan vergewissen moet. Dit forum kan voortdurend wisselen. Het kan een aardse rechter, de mensen in het algemeen, de gemeente of God Zelf zijn. Daarom is belijden geen spontane, onverbindende uiting geven aan zijn geloof, al evenmin een private of cultisch-liturgische lofverheffing alleen, maar vooral een verantwoorden, ergens voor staan en daarop staan met al de consequenties daaraan verbonden. En daarmee verbindt zich meestal, al of niet uitgesproken, een besliste afweer van het tegendeel. De meeste teksten, die van belijden spreken, zijn daarom ook van een eschatologische radicaliteit, zodat wie in dit belijden niet blijft zowel wat de geloofsacte als de geloofsinhoud aangaat, zodat hij aan Christus en zijn evangelie ontrouw wordt en een andere leer of evangelie brengt, onder het anathema gezet wordt. Zo zegt de Heiland zelf: Een ieder dan, die Mij belijden zal voor de mensen, die zal Ik ook belijden voor mijn Vader, die in de hemelen is, maar alwie Mij verloochenen zal voor de mensen, die zal Ik ook verloochenen voor mijn Vader, die in de hemelen is (Matt. $10: 32,33$ ). En de apostel Johannes verklaart: Een ieder die de Zoon loochent heeft ook de Vader niet. Wie de Zoon belijdt, heeft ook de Vader. En wij hebben aanschouwd en getuigen dat de Vader de Zoon gezonden heeft als Heiland der wereld. Alwie belijdt, dat Jezus de 
Zoon van God is - God blijft in hem en hij in God (1 Joh. $4: 14,15$ ). Dit wordt in de tweede brief nog eens krachtig onderstreept: Er zijn vele verleiders uitgegaan in de wereld, die de komst van Jezus Christus in het vlees niet belijden. Een ieder, die verder gaat en niet blijft in de leer van Christus, heeft God niet (2 Joh. 7, 9).

\section{Belijden op het evangelie Gods}

Daarbij is uit al deze gegevens duidelijk geworden, waarop het belijden betrokken wordt, nl. op Jezus Christus de Zoon van God in zijn persoon en werk. Het gaat daarin steeds om het evangelie Gods in Christus als de Heiland der wereld. Dit is van fundamentele betekenis in het vraagstuk, dat ons thans bezig houdt. Een belijdenis is geen stukje dogmatiek, geen theologisch tractaat, geen diepzinnige verhandeling. Alles wat ik geloof belijd ik niet, al behoort wel alles wat ik belijd tot mijn geloof. Alle geloofswaarheden, waarvan we vast overtuigd zijn, horen niet in de confessie thuis, maar alleen wat op het evangelie van Christus betrokken is. Laat me het met een variant op een woord van Calvijn tot Pighius mogen zeggen: Ik geloof, dat de Bijbel het theopneuste Woord Gods is, maar ik belijd het evangelie, dat mij daarin verkondigd wordt.

\section{Drie Formulieren van Enigheid als belijdenis}

Het is met grote dankbaarheid, dat ik getuigen kan, dat onze Drie Formulieren van Enigheid daaraan in het algemeen beantwoorden. Van de Heidelbergse Catechismus die alles in de enige troost samenvat, is het zonder meer duidelijk. Het opschrift boven de Nederlandse Geloofsbelijdenis: Der Nederlandsche kerken ware christelijke belijdenis, inhoudende de hoofdsom van de leer van God en der eeuwige zaligheid der zielen, is geen vlagvertoon, dat de lading niet dekt. Deze belijdenis kan niet over God spreken of terstond, even onafscheidelijk als zon en licht, wordt daaraan de eeuwige zaligheid der zielen verbonden. Als in het begin over Gods openbaring in zijn Woord gesproken wordt, dan wordt daarbij de karakteristieke bijvoeging geplaast: te weten zoveel als van node is en dit leven tot zijn eer en de zaligheid der zijnen. Onmiddellijk daarna wordt de inscripturatie van Gods Woord gezien als een duidelijke manifestatie van de bezondere zorg, die God van ons en onze zaligheid draagt. In het hart van de Confessie Belgica staat de lofzang op het geheimenis van de liefde Gods in Jezus Christus, die het sola fidei en het sola gratia onverkort en onverzwakt oproepen. En aan het slot staat de eschatologische belijdenis van de pelgrimerende kerk: Daarom verwachten wij die grote dag met een groot verlangen om ten volle te genieten de belofte Gods in Jezus Christus onze Heer.

Zelfs van de Dordtse Leerregels - al nadert dit de grens van een theologisch tractaat - de naam Canones spreekt hier boekdelen - moet gezegd worden dat zij ten diepste toch getrouw blijven aan de opzet: om naar de regel van Gods Woord te staan, Gods onverdiende genade en wegneming van alle menselijke verdienste en waar- 
digheid en de versterking van de vastheid van de geloofstroost der kinderen Gods.

Op deze kern van onze belijdenisgeschriften, op dit evangelie Gods in Christus Jezus is het bijbelse begrip van homologia als geloofsacte en geloofsinhoud ten volle van toepassing. Hier ligt hun geestelijke autoriteit, waaraan wij met lijf en ziel gebonden zijn. Hier is de evidentie van het evangelie Gods en de onfeilbare leiding des Geestes, die ons tot deze gehoorsaamheid van het belijden brengt. Hier ligt voor ons ook het "to be or not to be" en is deze belijdenis voor ons grensmarkerend. Hier vraagt de kerk terecht geloofsgehoorzaamheid en moet zij bij afwijking daarvan met judiciële, soms zelfs met juridische tuchtoefening, voor de zuiverheid van het evangelie en het behoud der zielen waken!

\section{Belijden in eigentijdse taal}

Tegelijk moet echter volop gerekend worden met het onloochenbaar feit, dat de kerk in haar pelgrimstocht door de eeuwen in haar forensische taak tegenover allerlei opgekomen haeresieën gesproken en beleden heeft in eigentijdse taal, denkpatroon, categoriale bepalingen en historische situaties waaraan niemand vandaag gebonden kan worden. Wij noemen ter illustratie enkele voorbeelden. Wij beginnen met de terminologie, waaraan men trouwens in de christelijke kerk van de oudste tijden af niemand gebonden heeft, zo de overeenstemming met de zaak, die men beleed, duidelijk was. De kerkvaders waren diep doordrongen van het inadequant karakter van tal van filosofische termen, die zij noodgedwongen tegenover de ketters moesten gebruiken. $U$ moet Hieronymus horen schelden tegen de dwaalleraars, die hem noodzaken de mysteriën Gods in het jargon van heidense filosofen te persen. Augustinus kent geen enkele aarzeling in het belijden dat God één is en toch drie, drie en toch één. De grote armoede van de menselijke uitdrukkingswijze, zo schrijft hij in De Trinitate, wordt echter openbaar, wanneer gevraagd wordt: hoe drie? Men zegt dan drie Personen, niet om het daarmee aan te geven, maar om niet te moeten zwijgen. Wie met de Christologische strijd in de Oude Kerk iets meer dan oppervlakkig bekend is, weet aan welke veranderingen reeds in die dagen deze termen onderworpen waren. In 268 wordt Paulus van Samosate op de synode van Antiochië veroordeeld, omdat hij leerde, dat de Zoon van God homo ousios was met de Vader. In 325 wordt uitdrukkelijk uitgesproken op het concilie van Nicea, dat de Zoon homo ousios is met die Vader. Op hetzelfde concilie van Nicea wordt in het decreat de term hypostase

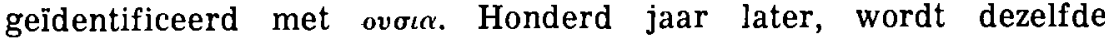
term hypostase in de Triniteitsleer uitdrukkelijk van ovoı $\alpha$ onderscheiden. In beide gevallen was het geen zakelijke koerswijziging, maar de termen krijgen een andere zin. Luther noemt hun, die bij zulke termen zweren kortweg vocabulisten. Calvijn verklaart in het geding met Caroli, dat het vitachtig is over woorden te twisten, wanneer men het over de zaak eens is. U kent ongetwijfeld zijn uitspraak: Mijnentwege mogen ze (hij bedoelt de termen persoon, wezen, sub- 
stantie e.d.) begraven worden, zo maar onder allen vaststond, dat Vader, Zoon en Heilige Geest één God zijn en dat toch de Zoon niet is de Vader noch de Geest de Zoon, maar dat zij door een bizondere eigenschap onderscheiden zijn.

\section{Denkpatronen en belijden}

Dezelfde geestelijke vrijheid bezitten we, al grijpt de zaak hier dieper in, ten opzichte van de denkkaders, de denkpatronen, waarin het belijden der kerk gezet is. Wij volstaan met twee voorbeelden. De statische, ontische categorieën van de twee naturenleer op het Concilie van Chalcedon. De Aristoletische invloed (denk aan de causale categorie en de fatale invloed daarvan; Aristoteles kent de historie niet en daarom komen op beslissende punten de heilshistorische factoren, die de Bijbelse leer bepalen, niet aan bod) in de Dordtse Leerregels: In zulke gevallen is de vraag beslissend of men met de zakelijke inhoud en de intentie van de belijdenis instemt. Calvijn heeft daarop alle nadruk gelegd bij zijn aanvaarding van de geloofsbelijdenis van Nicea. Hij veroordeelt daarin wat de vorm betreft de breedsprakigheid en de nuttelose omhaal van woorden (God uit God, licht uit licht, waarachtig God uit waarachtig God). In een samenvatting van de noodzakelijkste zaken behoort men met zo kort mogelijke formules te volstaan. Hij vond het meer een gedicht om gezongen te worden dan een geloofsbelijdenis, in éen woord te veel absurd. Maar ook op die inhoud oefent hij scherpe kritiek. Hij spreekt hier zelfs van battologie, van wartaal spreken, wanneer in deze belijdenis van "God uit God" gesproken wordt. En toch kan hij dit belijden aanvaarden en ondertekenen, omdat hij, zoals hij uitdrukkelijk verklaart, op de intentie, de goede bedoeling van de vaders let en vanuit de verklaring van Athanasius als een bevoegd getuige zich daarover heeft later informeren. Daaruit is hem gebleken, dat de vaders, om alle dubbelzinnigheden te achterhalen en alle uitvluchten af te snjden, zo sterk mogelijk hebben willen uitdrukken, dat Christus waarachtig God is en geen moment aan een tweede godheid of aan twee wezens gedacht hebben. Al blijft hij zulke harde spreekwijzen betreuren, zo kan hij, omdat de intentie hem duidelijk is, met de zakelijke inhoud van dit belijden van harte instemmen.

\section{Fundamentele en niet-fundamentele stukken in de Confessie}

Ten slotte zou ik op de historische situatie willen wijzen, die meebrengt dat wij vandaag in de Confessie tussen fundamentele en nietfundamentele stukken moeten onderscheiden. Neem de Heidelbergse Catechismus en de Confessio Belgica, ontworpen in een tijd, waarin men met name de overeenstemming met de oude, zuivere kerk der eerste vijf eeuwen (een fictie overigens) wilde beklemtonen en tegelijk met de breuk met de Lutherse kerk moest rekenen, waarvan niemand zeggen kan en Calvijn zijn leven lang het tegendeel verdedigd heeft, dat hier de geschillen grensmarkerend waren. Al beklemtonen we nogmaals met dankbaarheid dat het evangelisch-katholiek karakter 
in beide formulieren domineert, zo doet toch deze historische situatie haar invloed gelden. We geven weer een paar voorbeelden als staafkaart van ons bedoelen. In art. 19 van de Nederlandsche Geloofsbelijdenis wordt beleden: Maar intussen bleef de goddelijke natuur altijd verenigd met de menselijke ook zelfs toen hij in het graf lag en de Godheid hield niet op in hem te zijn. Dit is een dogmatische speculatie, die reeds bij enkele kerkvaders voorkomt, maar is geen belijdenis in de Bijbelse zin van dit woord. En in vr. 48 van de Heidelbergse Catechismus lezen we: „Maar zo de mensheid niet overal is waar de Godheid is, worden dan de twee naturen van Christus niet van elkander gescheiden? Ganselijk niet, want dewijl de Godheid door niets kan worden ingesloten en overal tegenwoordig is, zo moet volgen, dat zij wel buiten haar aangenomen mensheid is en nochtans persoonlijk met haar verbonden blijft". U mag dit extra calvinisticum in de controvers met de Lutheranen dogmatisch juist of aanvechtbaar achten, in een confessie in Bijbelse zin hoort zij niet thuis. Zulke extrapolaties wreken zich trouwens terstond, omdat niemand loochenen kan, dat deze vertolkte visie in het midden van de gemeente nooit echt geleefd heeft.

\section{Roeping tot ongerept bewaren van het evangelie}

Bij deze stand van zaken zal de kerk, aan wie de woorden Gods zijn toevertrouwd en de leiding van de Geest is toegezegd, als pijler en fundament der waarheid, moeten waken voor het ongerept bewaren van het evangelie van Christus, zoals dit in de Reformatietijd is verstaan en beleden en toch tegelijk als moeder der gelovigen ruimte moeten laten voor de eigentijdse vertaling daarvan, waarin niet alleen de terminologie, maar ook bepaalde kaders en denkstructuren van onze klassieke belijdenisgeschriften doorbroken worden. $\mathrm{Zij}$ zal de spanningsvolle eenheid van het quia en het quatenus moeten aandurven. Zij moet daarbij staan in de vaste overtuiging dat het quia zonder het quatenus leidt tot een orthodoxisme en confessionalisme, waarin het volk Gods astmatisch wordt en zijn forensische taak niet meer vervult in eigentijdse problematiek. En tegelijk moet zij verstaan, dat het quatenus zonder het quia oeverloze vrijheid en een gevaarlijke dominocratie meebrengt, waarbij datgene, waarmee de kerk staat of valt zelfs aan de geproclameerde individualistische willekeur kan worden prijsgegeven. Alleen in de spanningsvolle eenheid van beide wordt het devies van Groen van Prinsterer ook vandaag tot zegen van de kerk vervuld: ondubbelzinnig en toch onbekrompen!

Gelewer deur prof. dr. A. D. R. Polman te Potchefstroom 1969. 